\title{
CHARACTERIZATION, IDENTIFICATION AND OPTIMIZATION OF CHITINOLYTIC RARE ACTINOMYCETES ISOLATED FROM SINAI SOIL, EGYPT
}

\author{
Hamada Hosney Elbadawy ${ }^{1,2}$, Abdel Naser A. Kobisi², Azza A. Abdel-khalek ${ }^{2}$, M. A. El- \\ Badry ,Zeinab Khaled Abd El-Aziz ${ }^{3 *}$ \\ 1.Department of Botany and Microbiology, Faculty of Science (Boys), Al-Azhar \\ university, Cairo, Egypt \\ 2.Department of Plant Protection, Desert Research Center, Cairo, Egypt \\ 3.Department of Botany and Microbiology, Faculty of Science (Girls), Al-Azhar \\ university, Cairo, Egypt
}

*Corresponding author: E-mail: zeinabsaleh.el20@azhar.edu.eg

\begin{abstract}
Actinomycetes are highly economic and biotechnologically useful prokaryotes able to produce wide range of bioactive secondary metabolites such as antibiotics and enzymes. The present study, aimed to isolate and screen actinomycetes from various soil samples collected from different regions of Saini, Egypt for chitinase production. In instantaneous isolation and screening of actinomycetes from Sixty-one soil samples, only eight isolates were found to have the capability to produce chitinase on colloidal media. Actinomycete strain A13 exhibit highest chitinase production while other strain shown poor production as compared to an index of relative enzyme activity. The most potent chitinolytic actinomycete isolate No. A13 was selected for further studies concerning their identification. Morphological, physiological, and phylogenetic analysis (16S rRNA). In addition to biochemical studies and culture characteristics as well as the chemical analysis of the cell wall, were carried out for the isolate under study. Based on the phenotypic and genotypic accumulated characteristics of the most potent chitinolytic actinomycetes isolate and consulting the recommended International Key's of Bergey's Manual for identification of actinomycetes, it was found that this isolate matched with Amycolatopsis orientalis by $97 \%$ with some differences and was given the name Amycolatopsis orientalis A13 sp. nova.
\end{abstract}

The results revealed that the chitinase produced by Amycolatopsis orientalis A13 sp. nova can be optimized to produce the highest yield of chitinase and used as biocontrol agent.

Keywords: rare, Actinomycetes, Chitinolytic, Saini soil, chitinase, optimization 


\section{Introduction}

Actinomycetes are filamentous Gram-positive bacteria, characterized by a complex life cycle belonging to the phylum Actinobacteria, which represents one of the largest taxonomic units among the 18 major lineages currently recognized within the Domain Bacteria. Actinobacteria are widely distributed in both terrestrial and aquatic ecosystems, mainly in soil, where they play an essential role in recycling refractory biomaterials by decomposing complex mixtures of polymers in dead plants, animals, and fungal materials. They are also important in soil biodegradation and humus formation as they recycle the nutrients associated with recalcitrant polymers, such as chitin, keratin, and lignocelluloses (Mukesh et al., 2014). For more than a decade, actinomycetes, Aspergillus fumigatus, and Penicillium sp. have been recognized as the dominant culturable micro-organisms in composting bioaerosols (Wéry, 2014). Enzymes created by Actinomycetes are rates as potential biocatalysts to bring of many specific reactions. Enzymes originated from Actinomycetes source are generally noticed as safe for the environments and they are functional at a wide range of temperature, $\mathrm{pH}$ or other extreme conditions (Mukhtar et al., 2017).

A few Actinomycetes genera have the ability to produce some types of chitinases when grown on chitin substrate, some actinomycetes genera (Aeromicrobium, Microbacterium, Nocardioides, and Solirubrobacter) were detected only on chitin-media (Jacquiod et al., 2013).

Medium with chitin as the sole nitrogen and carbon source could be selective for isolation of Actinomycetes (Lingappa \& Lockwood, 1961; Hsu \& Lockwood, 1975; Lacombe-Harvey et al., 2018). When grown on solid medium containing the colloidal chitin as a sole Carbon source, clearing zone surrounding colonies reveals that their growth depends, at least the evidence on their capability to solubilize chitin(Lacombe-Harvey et al., 2018; Yildirim-Aksoy et al., 2019).

Chitin agar is still used for selective isolation of chitinolytic actinomycetes as well as actinomycetes interacting with plants (Golinska et al., 2015). Several chitinolytic actinomycetes strains have been found to protect plants against plant diseases or to promote their growth. Some of these chitinolytic strains can even assume an endophytic means after their pass in plant tissues through cross root development areas, other natural openings or wounds (Santi et al., 2013). Chitinolytic actinomycetes strains used as commercial fungicides (Doumbou et al., 2001; Rey \& Dumas, 2017). Although biocontrol has been shown to contribute to plant protection (Doumbou et al., 2001), chitinases produced by the actinomycetes are also thought to participate in antagonistic interactions with pathogenic fungi (El-Tarabily et al., 2000; Rey \& Dumas, 2017).

The present study aimed to isolate, identification, and characterization of the most prominent chitinolytic actinomycete bacteria from soil sample (desert soil of El Tur, Sinai) and optimization of production parameters for maximum chitinase production. 


\section{Material \& Methods}

\section{Isolation of Actinomycetes from soil sample:}

\section{Soil sampling}

Sixty-one soil samples were collected from different locations from Egyptian Desert regions Sinai (El Tur, Nwaba, Ras Sidr and Saint Catherin) .Every sample was a mixture of soil collected from 3 to 5 holes whose depth was around 10 to $20 \mathrm{~cm}$ (Yassine, 2013). The surface layer of soil removed, and the central portion was collected in sterile plastic bags. Samples mixed to ensure uniformity and passed through a $3 \mathrm{~mm}$ sieve to remove stone and root fragment.

\section{Processing of soil samples}

Each sample was divided into two parts. One part was used as air dryer for one week at room temperature to be used as dry sample and the second part was taken as the preliminary treatment of soil samples by $1: 10 \mathrm{w} / \mathrm{w} \mathrm{CaCO}_{3}$ with $\mathrm{A}$ high relative humidity was maintained in the jar by water saturated filter paper and incubated it for several days at $28^{\circ} \mathrm{C}$. Such procedure proved to be rather efficient in regard to increasing the number of the isolates including representatives of rare genera as compared with the routine methods and this helps in reducing the relative counts of bacteria and molds (Alferova \& Terekhova, 1988).

\section{Actinomycetes isolation}

For isolation of Actinomycetes colonies, the dilution method described by (Oskay et al., 2004) was used. Suspensions of soil samples were prepared by shaking $5 \mathrm{gm}$ of the soil in $50 \mathrm{ml}$ sterile distilled water, allowed to stand for $10 \mathrm{~min}$. Serial dilutions were prepared from $10^{-1}$ to $10^{-10}$ using sterile distilled water. Under aseptic conditions, $0.1 \mathrm{ml}$ of each dilution was spread by a glass spreader on Starch Nitrate agar and Yeast-Malt Extract (ISP2) agar plate ( Shirling and Gottlieb, 1996) and incubated for 7 days at $28-30{ }^{\circ} \mathrm{C}$.

The developed colonies of Actinomycetes which are characterized by their sharp round edges on culture medium are picked up by a sterile needle and then re-inoculated on the isolation medium, sub-cultured on slants of the same medium and stored for studies.

\section{Primary Screening for enzyme activity of Actinomycetes isolates}

\section{Preparation of colloidal chitin}

Colloidal chitin was prepared by the method of (Hsu \& Lockwood, 1975) with some our modifications as follows. The practical grade chitin powder purchased from (QualiKems, India) was used to prepare the colloidal chitin. Chitin powder (5 g) was 
dissolved in $100 \mathrm{ml}$ of ice concentrated hydrochloric acid and continuously stirring at $4{ }^{\circ} \mathrm{C}$ for $2 \mathrm{~h}$. Chitin was precipitated as a colloidal suspension by adding it slowly to $500 \mathrm{ml}$ of ice $95 \%$ ethanol with continuously stirring at $4{ }^{\circ} \mathrm{C}$ for $1 \mathrm{~h}$ and then incubate at $27^{\circ} \mathrm{C}$ overnight. The suspension was centrifuged at $4^{\circ} \mathrm{C}$ for $15 \mathrm{~min}$ at $3000 \mathrm{rpm}$ and the $\mathrm{pH}$ of precipitate after dissolving in distilled water was adjusted to 7.0 by addition of $5 \mathrm{~N} \mathrm{NaOH}$ and the colloidal suspension was washed with distilled water for desalting. After desalting, the suspension was centrifuged at $3000 \mathrm{rpm}$ for $15 \mathrm{~min}$ at $2^{\circ} \mathrm{C}$ and the precipitate was collected for further use as colloidal chitin.

\section{Screening for production of chitinase activity}

\section{Qualitative assay}

Chitinolytic ability of the actinomycetes isolated from soil samples were determined using the effects of different media supplemented with colloidal chitin $(0.1 \%)$. Chitinase production were tested using three culture media, basal medium (Vyas \& Deshpande, 1989) colloidal chitin medium (Deng et al., 2007) and ISP2 with replacing glucose with Colloidal chitin (ISP2CC). Each plate containing media was inoculated with a loop of growing margins of six- day-old isolates on a Yeast-Malt Extract (YEME) plate and incubated for 7 days until zone of chitin clearing were seen around and beneath the colonies. Clear zone diameter was measured in $(\mathrm{mm})$ at the average of three-dimension measure and used as an indicator of chitinase activity. An index of relative enzyme activity (RA) for each isolate was calculated by dividing the total area of activity (the area of the clearing zone less the area of the colony) by area of the colony of 1 or greater (Bradner et al., 1999; Duncan et al., 2006).

\section{Quantitative determination of chitinase}

Individual 250-ml Erlenmeyer flask containing $50 \mathrm{ml}$ of ISP2 without glucose broth amended with $10 \mathrm{mg} / \mathrm{ml}$ of colloidal chitin were prepared. Flask containing broth media as above were inoculated with a culture disk $(5 \mathrm{~mm}$ diameter) taken from the growing margins of six-day-old isolates on a Yeast-Malt Extract plate of actinomycete isolate and incubated for 7 days (Balouiri et al., 2016). After incubation, the suspension from each flask were icecentrifuged for $30 \mathrm{~min}$ at $13000 \mathrm{~g}$. The supernatant was collected in sterile tubes and was used as a source of the crude enzymes.

\section{Chitinase Enzyme assay}

Chitinase activity was determined according to the method described by (Tweddell et al., 1994) and modified by (Reissig et al., 1955; Singh et al., 1999). The reaction mixture consisting of $1 \mathrm{~mL}$ of colloidal chitin $(1 \%)$ in $50 \mathrm{mM}$ sodium phosphate buffer, $\mathrm{pH} 6.8$ and $1 \mathrm{~mL}$ of enzyme solution. After incubation at $50{ }^{\circ} \mathrm{C}$ for 1 hour, the reaction was stopped by boiling, centrifuged and chitinase activity was calculated by measuring the release of $\mathrm{N}$ acetyl -D-glucose amine (NAG). Reducing sugar concentration was determined by optical 
density at $570 \mathrm{~nm}$ using a scanning spectrophotometer (UV). $\mathrm{N}$-acetylglucosamine used as the calibration standard. The concentration of NAG in the supernatant is determined by the procedure of Reissig et al (1955). Specific activity (U=1 unit of chitinase) was defined as the amount of the enzyme that released $1 \mu$ mol of NAG mg ${ }^{-1}$ protein $\mathrm{h}^{-1}$. The concentration of protein was estimated by Lowry's method (Lowry et al., 1951) using bovine serum albumin as standard.

\section{Optimization of enzyme production}

The effect of different operational parameters on chitinase production was optimized further. About 1\% culture was inoculated into the previously mentioned medium and evaluated one by one keeping other factors constant. For the determination of optimum temperature, the chitinase production medium was prepared in different flasks and the chitinase production was assayed after incubating the medium at different temperatures $\left(20,25,28,30,35,40\right.$ and $\left.45{ }^{\circ} \mathrm{C}\right)$. The optimum $\mathrm{pH}$ for the chitinase production was investigated by varying the initial $\mathrm{pH}$ of the culture medium from 5 to 9 and at optimized temperature. For the determination of optimum incubation time for chitinase production, the isolate was allowed to grow for various incubation periods viz: 4, 5, 6, 7, 8, 10 and 11 days at $30{ }^{\circ} \mathrm{C}$., Effect of different colloidal chitin concentrations on the chitinase productivity were tested. For the determination of optimum nitrogen source our organic nitrogen sources (arginine and tryptone), two inorganic nitrogen sources (ammonium nitrate and ammonium sulphate) were added to production media. Where carbon source optimized by ISP 2 medium lacking its carbon sources was supplemented with different types of sugars at equi-molecular amounts of carbon sources. The carbon sources were represented by, D-glucose, D-fructose, soluble starch, sucrose, tween80, and glycerol, centrifuged at 10,000 rpm for $15 \mathrm{~min}$ and the supernatant was subjected to chitinase assay.

Methods used for classification of the most potent chitinase-producing actinomycete isolate No. A 13

\section{Conventional taxonomy}

\section{(a) Studies concerning the morphological characteristics}

Determination of the spore-bearing hyphae and spore chains morphology were done by cover slip culture technique (Kawato \& Shinobu, 1959) or by direct microscopically examination to the surface of the culture on the growth plates. Electron microscope study was done for spore chain morphology and spore surface.

\section{(b) Studies concerning the cultural characteristics}

Diaminopimelic acid (DAP) in the whole cell was analyzed according to (Becker $\boldsymbol{e t}$ al., 1964) and (Yamaguchi, 1965). The color of sporulating aerial mycelium, substrate mycelium and soluble pigments in media were recorded in accordance with the guidelines 
established by the International Streptomyces Project (Shirling \& Gottlieb, 1966) ISP methods. Colors were assessed on the scale developed by (Kelly \& Judd, 1976).

(c) Studies concerning the physiological properties

Was carried out according (Tresner \& Danga, 1958; Pridham \& Gottlieb, 1948; Shinobu, 1958; Pridham and Gottlieb 1948).

\section{Molecular and phylogenetic identification:}

\section{DNA isolation and amplification of 16S rRNA gene:}

A single, pure colony of the isolate was taken from the plate grown culture and was

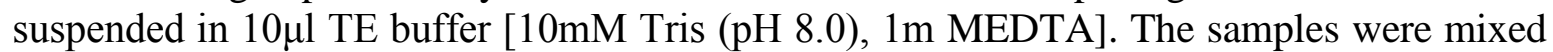
briefly using cyclo mixer, and $5.0 \mu$ l of this suspension was applied to FTA ${ }^{\circ}$ Classic Card (Whatman International Ltd.) and allowed to dry for at least $1 \mathrm{~h}$ at room temperature. Further processing of the sample was done according to the manufacturer's instructions.

The 16S rRNA genes were amplified using forward (5'- AGA GTT TGA TCC TGG CTC AG -3') and reverse (5'- GGT TAC CTT GTT ACG ACT T-3') primers (Xcelris Labs Ltd., India) known to be conserved among all known bacteria (Ulrike et al. 1989). PCR was performed in an automated thermal cycler (PTC-200, M J Research Inc.) with an initial $92^{\circ} \mathrm{C}$ denaturation for $2 \mathrm{~min} 10 \mathrm{sec}$; followed by 35 cycles of $92^{\circ} \mathrm{C}$ for $1 \mathrm{~min} 10 \mathrm{sec}, 48^{\circ} \mathrm{C}$ for $30 \mathrm{sec}, 72^{\circ} \mathrm{C}$ for $2 \mathrm{~min} 10 \mathrm{sec}$ and a final extension at $72^{\circ} \mathrm{C}$ for $6 \mathrm{~min} 10 \mathrm{sec}$ (Massol-Deya et al., 1995). The PCR products were resolved by electrophoresis on $1.5 \%$ agarose gel (BioRad, Hercules, CA) and visualized using gel documentation system (UVI pro, UVI tec). DNA isolation and purification, 16S rRNA gene amplification and sequencing was carried out at Genetic Analyzer Unit; Sigma Scientific Services Co., El-Dokki, Egypt.

\section{Results and Discussion}

\section{Isolation of actinomycetes from soil samples.}

A total of 18 morphologically different actinomycetes were isolated from Sixty-one soil samples collected from different locations from Egyptian Desert regions Sinai (El Tur, Nwaba, Ras Sidr and Saint Catherin).

\section{Qualitative determination of chitinolytic activity}

Only Eight isolates have the capability to produced chitinase on colloidal chitin (CC) media and ISP 2 supplemented by colloidal as Carbon source (ISP2CC) showed by clear zone formed around them, these eight isolates were 7A1, 7A2, 11, A2, 32, A13,23M and 22. No growth was observed on CC medium except isolates No.11,23M. When these isolates compared according to calculating of An index of relative enzyme activity (RA) for each 
isolate, A13 was ranked as the most potent chitinolytic actinomycete producer (Table 1,Fig. 1) and was chosen for further studies.

\begin{tabular}{|l|c|c|c|}
\hline Isolation & $\begin{array}{l}\text { Mean of colony diameter } \\
(\mathrm{mm})\end{array}$ & Mean of clear zone diameter $(\mathrm{mm})$ & RA \\
\hline $\mathbf{A 1 3}$ & 10.67 & 28.33 & 1.656 \\
\hline $\mathbf{7 A 2}$ & 4.50 & 6.00 & 0.333 \\
\hline $\mathbf{2 2}$ & 9.50 & 10.50 & 0.105 \\
\hline $\mathbf{1 1}$ & 5.00 & 9.43 & 0.887 \\
\hline $\mathbf{7 A 1}$ & 12.67 & 18.33 & 0.447 \\
\hline $\mathbf{A 2}$ & 10.50 & 14.50 & 0.381 \\
\hline $\mathbf{3 2}$ & 9.67 & 13.67 & 0.414 \\
\hline $\mathbf{2 3 M}$ & 6.17 & 11.33 & 0.838 \\
\hline
\end{tabular}

$\mathbf{R A}=$ An index of relative enzyme activity

Table 1: An index of relative enzyme activity (RA) for isolates on ISP2CC media.

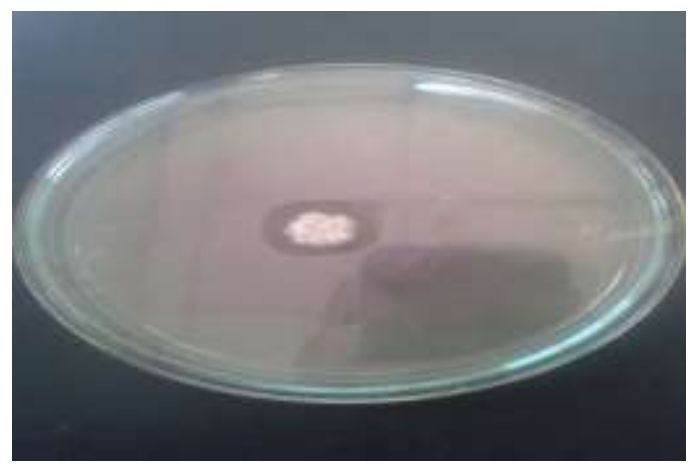

Figure 1: Evaluation of Chitinolytic activity assay

\section{Quantitative determination of chitinase}

The most potent isolate for chitinolytic activity (A13) grew well on Colloidal Chitin broth medium (CC) and ISP2 supplemented with colloidal chitin as sole source of Carbon (ISP2CC). The chitinolytic activity were recorded for CC Broth media as triple replicate with chitinase activity as following $132.94,165.32,153.25 \mathrm{U} / \mathrm{ml}$ and protein measure 6.05 , 7.30, 6.89 U/mg while for ISP2CC recording chitinase activity as 262.80, 286.47, $293.47 \mathrm{U} / \mathrm{ml}$ and protein measuring $5.361,5.880,10.571 \mathrm{U} / \mathrm{mg}$, so ISP2CC medium was selected for further procedures.

Taxonomic studies of the most potent chitinase-producing actinomycete isolate No. A13

The morphological, physiological, cultural, and biochemical characteristics for isolate No. A13 were carried out (Tables 2, 3 and Figures 3, 4). 


\begin{tabular}{|l|l|l|l|l|}
\hline Types of media & Growth & $\begin{array}{l}\text { Aerial } \\
\text { mycelium }\end{array}$ & $\begin{array}{l}\text { Substrate } \\
\text { mycelium }\end{array}$ & $\begin{array}{l}\text { Diffusible } \\
\text { pigments }\end{array}$ \\
\hline Starch-nitrate agar & $+^{\mathrm{p}}$ & white & yellow & $\begin{array}{l}\text { Yellowish } \\
\text { brown }\end{array}$ \\
\hline $\begin{array}{l}\text { Inorganic-trace salt- starch } \\
\text { agar (ISP 4) }\end{array}$ & $+^{\mathrm{p}}$ & white & Pale yellowish & $\begin{array}{l}\text { Yellowish } \\
\text { brown }\end{array}$ \\
\hline $\begin{array}{l}\text { Glycerol asparagine agar } \\
\text { (ISP 5) }\end{array}$ & + & white & cream & - \\
\hline $\begin{array}{l}\text { Yeast extract- malt extract } \\
\text { agar (ISP 2) }\end{array}$ & + & white & Pale yellowish & + -- purple \\
\hline Oatmeal agar (ISP 3) & + & white & Pale yellowish & - \\
\hline $\begin{array}{l}\text { Melanin pigment media } \\
\text { 1-Tryptone yeast extract } \\
\text { (ISP 1) }\end{array}$ & + & white & yellow & - \\
\hline $\begin{array}{l}\text { 2- Peptone yeast extract iron } \\
\text { agar (ISP 6) }\end{array}$ & + & white & Pale yellowish & - \\
\hline 3- Tyrosine agar (ISP 7) & + & white & cream & Purple \\
\hline
\end{tabular}

+ grow - absent $\quad+/$ - produced after long period incubation $\quad{ }^{\mathrm{p}}$ poor

Table 2: Cultural and physiological characteristics of the actinomycetes isolate No. A13.

\begin{tabular}{|l|l|}
\hline Characters & Isolate A13 \\
\hline Morphological characters: & \multicolumn{2}{|l|}{} \\
\hline Spore mass & Brilliant gray \\
\hline Spore chain & fragmenting branched aerial hyphae \\
\hline Spore surface & Smooth \\
\hline Diffusible pigment & + \\
\hline Physiological characters: & \multicolumn{2}{|l|}{} \\
\hline DAP & meso-DAP \\
\hline Pattern Sugar & Arabinose and galactose \\
\hline Melanin pigment & - \\
\hline Growth at $45^{\circ} \mathrm{C}$ & - \\
\hline Resistance to & R \\
\hline Rifampicin $(10 \mu \mathrm{g} / \mathrm{ml})$ & $\mathrm{R}$ \\
\hline Penicillin $\mathrm{G}(20 \mu \mathrm{g} / \mathrm{ml})$ & $\mathrm{R}$ \\
\hline Gentamycin $(5 \mu \mathrm{g} / \mathrm{ml})$ & $\mathrm{R}$ \\
\hline Tobramycin $(50 \mu \mathrm{g} / \mathrm{ml})$ & $\mathrm{R}$ \\
\hline Neomycin $(8 \mu \mathrm{g} / \mathrm{ml})$ & $\mathrm{R}$ \\
\hline Streptomycin $(20 \mu \mathrm{g} / \mathrm{ml})$ & \\
\hline Growth at $(\% \mathrm{w} / \mathrm{v}):$ & - \\
\hline NaCl $(7.0)$ & \\
\hline
\end{tabular}




\begin{tabular}{|l|l|}
\hline Utilization of: & + \\
\hline Sucrose & + \\
\hline meso-Inositol & + \\
\hline Mannitol & + \\
\hline Glucose & + \\
\hline Arabinose & + \\
\hline Fructose & + \\
\hline Glycerol & + \\
\hline Maltose & + \\
\hline Mannose & + \\
\hline Xylose & + \\
\hline Adonitol & + \\
\hline Cellobiose & + \\
\hline Tween 80 & \\
\hline
\end{tabular}

$(+)=$ positive,$(-)=$ negative $(\mathrm{R})=$ Resistant

Table 3: Morphological and biochemical characteristics of actinomycetes isolate No. A13

Molecular Identification of the most potent chitinase-producing actinomycete isolate A13

The 16S r-RNA gene sequencing of strain A13 resulted in 97\% of similarity with Amycolatopsis orientalis, therefore the strain A13 was designated as Amycolatopsis orientalis strain A13 which was submitted in the NCBI GenBank and accession number MN704757.1 was obtained. The phylogenetic tree of strain A13 was constructed by calculating bootstrap values by neighbor tree joining method which has been presented in Figure 2.

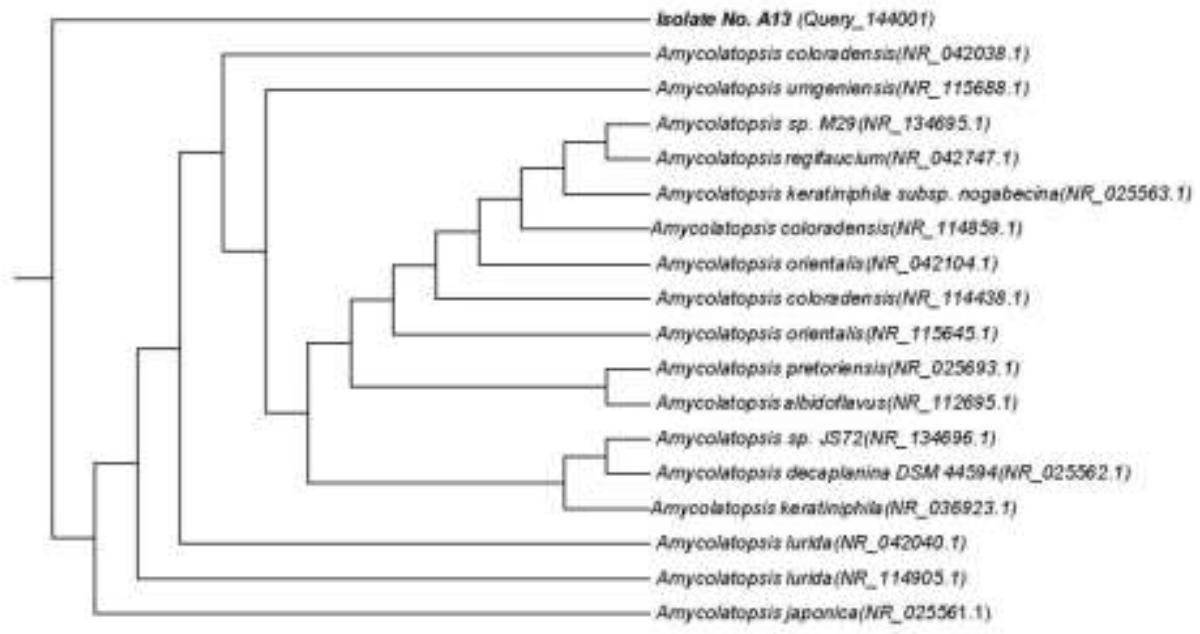

Figure 2: Phylogenetic Tree Representing Position of Strain A13 With Neighbor Joining Method. 


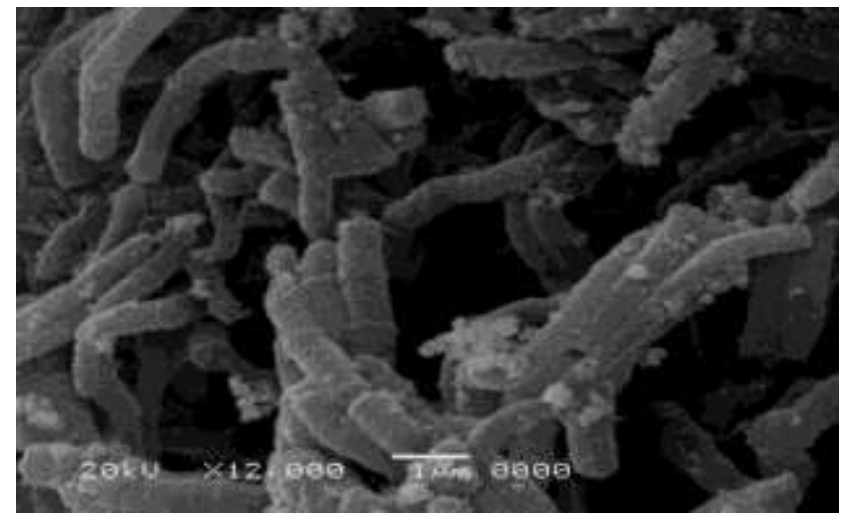

Figure 3: Scanning electron microscopy of Amycolatopsis orientalis A13 sp. nova.

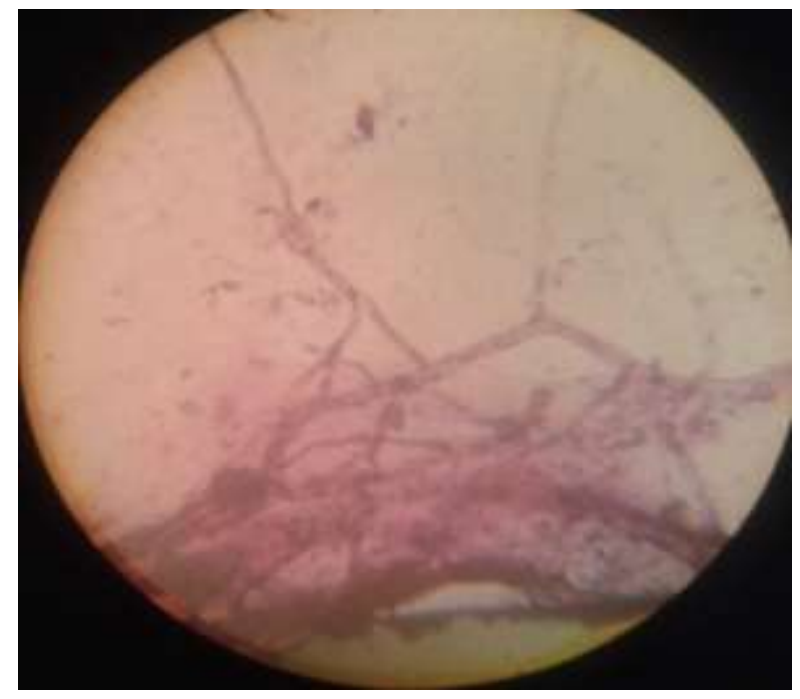

Figure 4: Light microphotograph of Amycolatopsis orientalis A13 sp. nova (400X).

From eighteen isolates showed chitinolytic activity, isolate No. A13 showed the strongest activity. The identification of isolate No. A13 was done according to Bergey`s Manual (Bergey \& Holt, 1994; Williams, 1989), in which the basis for the definition depends on the morphological characteristics and the pigments produced in addition to the physiological and genetic studies (amplification and sequencing of the 16S rRNA).

Therefore, it was found that isolate No. A13 matched with Amycolatopsis orientalis by 97\% with some differences and was given the name Amycolatopsis orientalis A13 sp. nova.(Nanjo et al., 1990) was first who purify the chitinase from Nocardia orientalis (present name: Amycolatopsis orientalis), (Murata et al., 2005) also reported chitinase enzyme from the culture filtrate of Amycolatopsis orientalis 


\section{Optimization of chitinase production by Amycolatopsis orientalis A13 sp. nova.}

\section{Effect of different incubation temperatures on the chitinase production}

For the detection of the suitable incubation temperature for maximizing chitinase activity, it could grow on growth medium adjusted at $\mathrm{pH}$ (7) and incubated at different temperatures covering the rang from $20-45^{\circ} \mathrm{C}$ for 6.0 days. Data represented graphically in Figure (5) revealed that, the optimum temperature capable of promoting chitinase productivity by Amycolatopsis orientalis Al3 sp. nova was at $30{ }^{\circ} \mathrm{C}$. Similar observation were also reported by (Kim et al., 2003) with Streptomyces sp. $M-20$ other reports also maximum enzyme production from Bacillus $s p . R 2$ at $30^{\circ} \mathrm{C}$ (Cheba et al., 2018).In general, most of the soil borne Streptomyces sp. showed the optimum temperature for maximum chitinase production lies between 30 to $40^{\circ} \mathrm{C}$ (Gomes et al., 2001; Shanmugaiah et al., 2008; Subramaniam et al., 2012).

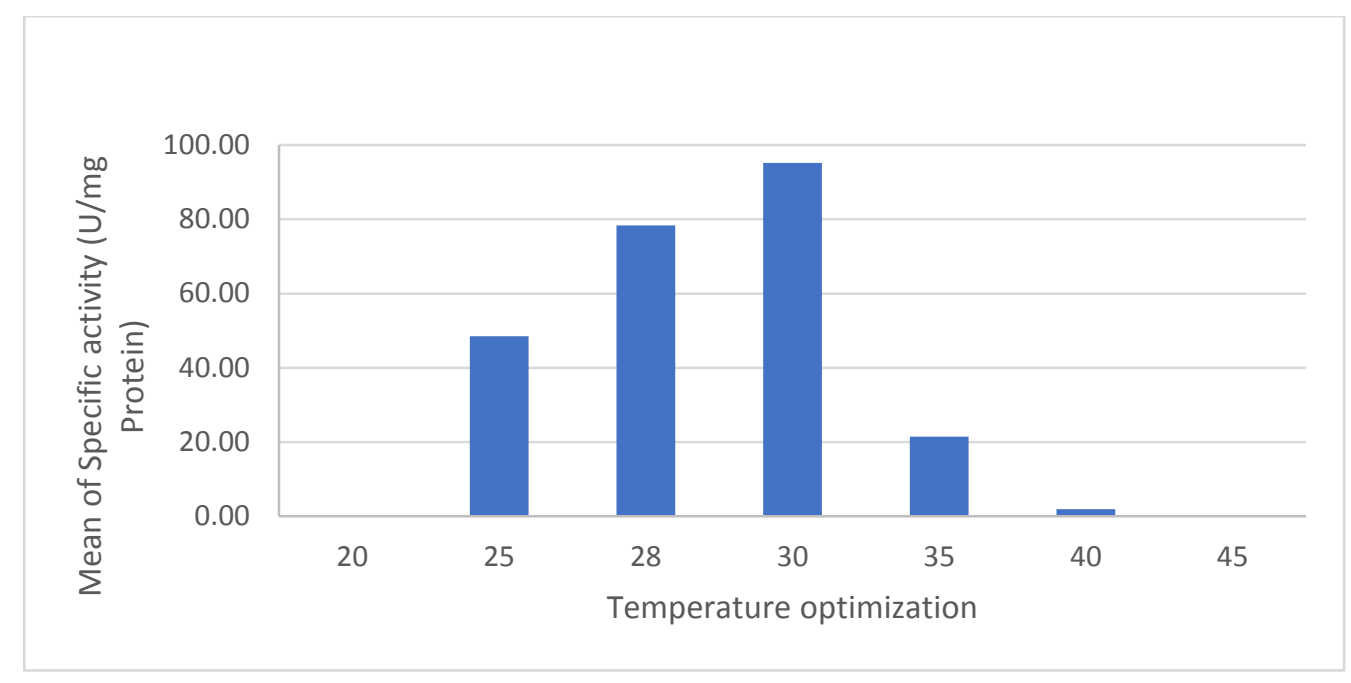

Figure 5: Effect of different incubation temperatures on the chitinase production by Amycolatopsis orientalis A13 sp. nova.

\section{Effect of the initial pH values on the chitinase production}

Effect of different initial $\mathrm{pH}$ values on the enzyme specific activity produced by Amycolatopsis orientalis A13 sp. nova was studied. For this purpose, growth medium was adjusted at different initial $\mathrm{pH}$ values covering the rang of (5-8) and incubated at $30{ }^{\circ} \mathrm{C}$ for six days. It could be concluded from the results represented graphically in Figure (6) that; the optimum initial $\mathrm{pH}$ value capable of promoting activity of Enzyme biosynthesis by Amycolatopsis orientalis A13 sp. nova was found to be at the value of 6.0. Below and above this $\mathrm{pH}$ value the enzyme(s) yield decreased gradually. Similarly, (Jahangiri $\boldsymbol{e t}$ al., 2019) reported the enzymatic activity of purified chitinases from Aeromonas sp. PTCC 1691 was optimal between $\mathrm{pH} 6$ and 8 , with a maximum at 6.(Donderski \& 
Trzebiatowska, 2000) showed the maximum activity of chitinases produced by planktonic bacteria at $\mathrm{pH} 6.0$ and at $30^{\circ} \mathrm{C}$.

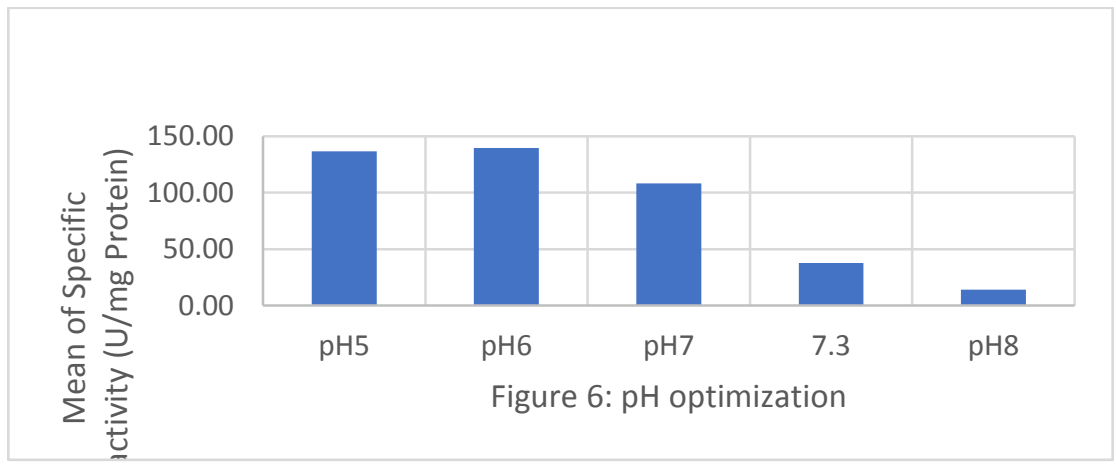

Figure 6: Effect of the initial $\mathrm{pH}$ values on the chitinase production by Amycolatopsis orientalis A13 sp. nova.

\section{Effect of different incubation periods on production of chitinase}

This experiment was conducted to detect the suitable incubation period needed to produce the highest yield of chitinase by Amycolatopsis orientalis A13 sp. nova. The chitinase productivity was detected at time intervals of $4,5,6,7,8,10$ and 11 days on ISP2CC medium, in submerged conditions. Data illustrated graphically in Figure (7) revealed the relation between specific activity of Enzyme and time of incubation that gave rise to a higher chitinase synthesis after 4 days of incubation and decreased thereafter while show slight increase after 11-day due production of pigmentation that interfere with assay. Similar observation was also reported by (Miranda-Chavez, 1978) with Streptomyces albus and S. griseus.(Karunya et al., 2011) reported the highest chitinase production at 4 days from Bacillus subtilis.

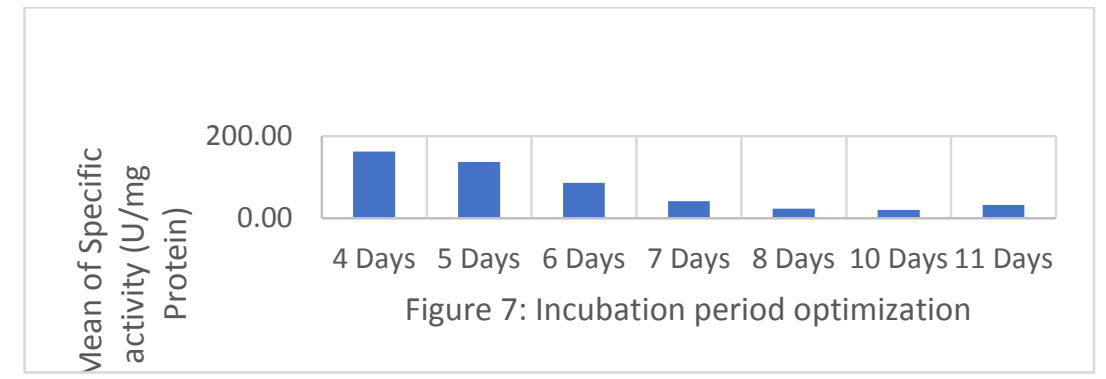

Figure 7: Effect of different incubation periods on production of chitinase by Amycolatopsis orientalis A13 sp. nova. 


\section{Effect of different colloidal chitin concentrations on the chitinase production}

The effect of different colloidal chitin concentrations on the chitinase productivity by Amycolatopsis orientalis A13 sp. nova was tested by add different concentrations of colloidal chitin to ISP2CC media viz: 3, 5, 10,15 and $20 \mathrm{mg} / \mathrm{ml}$ were applied as represented graphically in Figure (8). Maximum activity of the chitinase was recorded in the presence of colloidal chitin at $5 \mathrm{mg} / \mathrm{ml}$. Similar observation were reported that the optimal concentration ranged between 0.5 and $1 \%$ by(Cheba \& Zaghloul, 2017) with Bacillus sp.

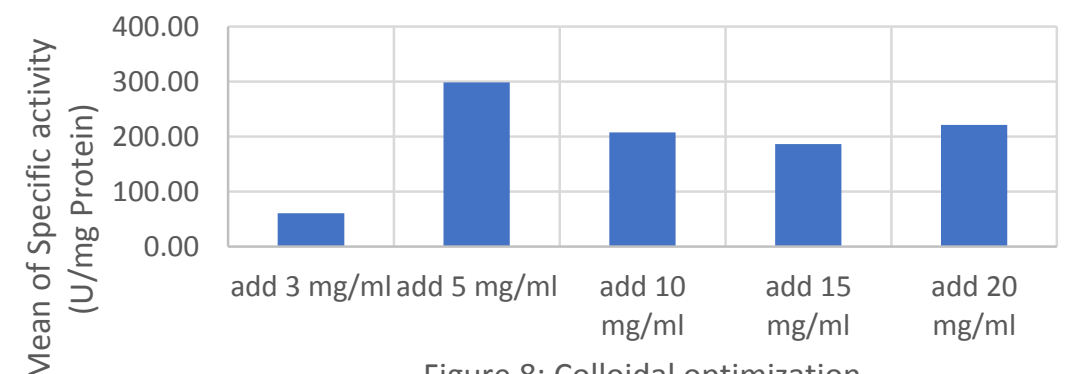

Figure 8: Colloidal optimization

Figure 8: Effect of different colloidal chitin concentrations on the chitinase production by Amycolatopsis orientalis A13 sp. nova.

\section{Effect of supplying different nitrogen sources on the chitinase production:}

The effect of different nitrogen sources on the chitinase productivity by Amycolatopsis orientalis A13 sp. nova was tested by add other nitrogen sources to ISP2CC medium where, four different nitrogen sources with different conc. viz: organic form such as arginine, tryptone and inorganic form as $\mathrm{NH}_{4} \mathrm{NO}_{3}$, and $\left(\mathrm{NH}_{4}\right)_{2} \mathrm{SO}_{4}$ were applied as represented graphically in Figure (9). Maximum activity of the chitinase was recorded in the presence of ammonium nitrate $0.06 \mathrm{~g} / \mathrm{ml}$.(Gangwar et al., 2016; Shalaby et al., 2019) reported The maximum chitinase activity was obtained from medium supported by Ammonium nitrate as nitrogen source. 


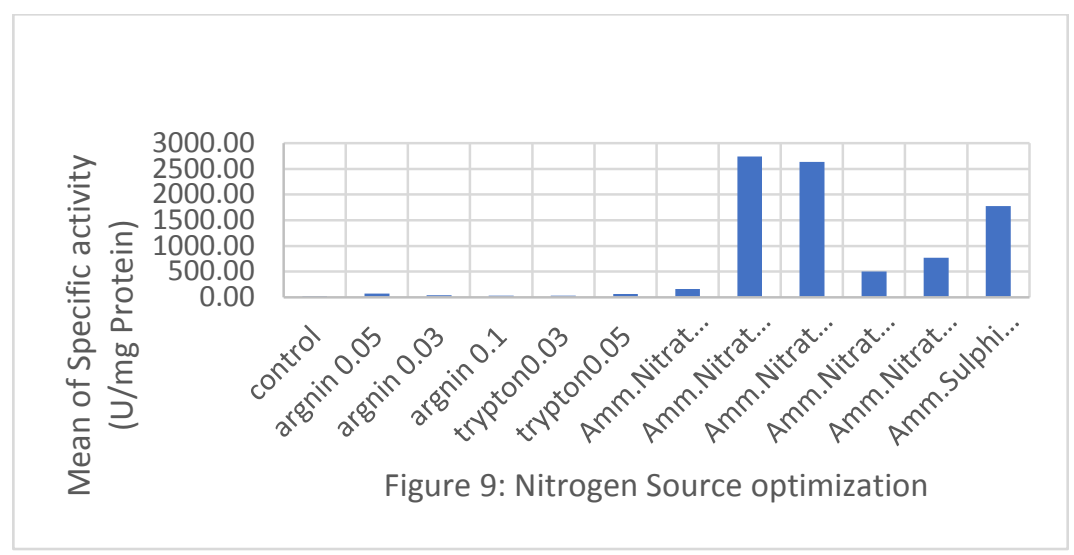

Figure 9: Effect of supplying different nitrogen sources on the chitinase production by Amycolatopsis orientalis A13 sp. nova.

\section{Effect of supplying different carbon sources on the chitinase production:}

For the detection of the suitable carbon source for maximizing the chitinase productivity by Amycolatopsis orientalis A13 sp. nova, it could grow on growth medium containing different carbon sources viz: D-glucose, D-fructose, soluble starch, sucrose, glycerol, and tween 80. Data represented graphically in Figure (10) revealed that, the highest chitinase activity could be obtained in the presence of commercial D-fructose followed by D-glucose. (Shivalee et al., 2018) showed formulated production medium supplemented with fructose greatly influenced the chitinase production by Streptomyces pratensis strain KLSL55.

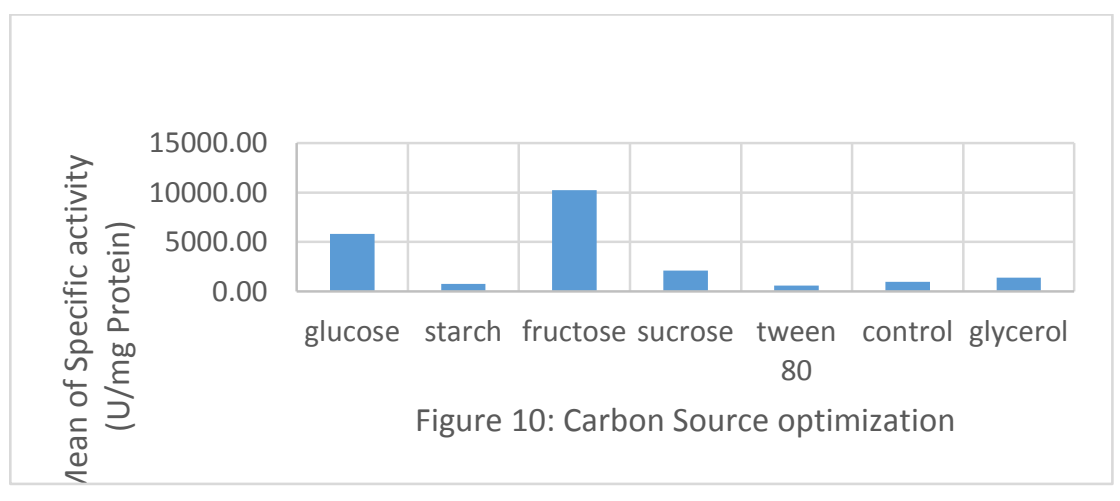

Figure 10: Effect of supplying different carbon sources on the chitinase production by Amycolatopsis orientalis A13 sp. nova.

\section{Conclusion}

Several actinomycetes isolates were isolated from different Sinai areas can produce chitinase enzyme. This study implies that the presence of highest chitinolytic activity of $A$. 
orientalis A13 sp. nova and the Results of this experiment could be considered in improving the strategy to use as a biocontrol agent.

\section{REFERENCES:}

Alferova, I. V, \& Terekhova, L. P. (1988). Use of the method of enriching of soil samples with calcium carbonate for isolation of Actinomyces. Antibiotiki $i$ Khimioterapiia= Antibiotics and Chemoterapy [Sic], 33(12), 888-890.

Balouiri, M., Sadiki, M., \& Ibnsouda, S. K. (2016). Methods for in vitro evaluating antimicrobial activity: A review. Journal of Pharmaceutical Analysis, 6(2), 71-79. https://doi.org/10.1016/j.jpha.2015.11.005

Becker, B., Lechevalier, M. P., Gordon, R. E., \& Lechevalier, H. A. (1964). Rapid differentiation between Nocardia and Streptomyces by paper chromatography of whole-cell hydrolysates. Applied Microbiology, 12(5), 421-423.

Bergey, D. H., \& Holt, J. G. (1994). Bergey's manual of determinative bacteriology, Williams and Wilkins. Baltimore, MA.

Bradner, J. R., Gillings, M., \& Nevalainen, K. M. H. (1999). Qualitative assessment of hydrolytic activities in antarctic microfungi grown at different temperatures on solid media. World Journal of Microbiology and Biotechnology, 15(1), 143-145. https://doi.org/10.1023/A:1008855406319

Cheba, B. A., \& Zaghloul, T. (2017). Effect of Carbon Sources on Bacillus sp . R2 Chitinase Production. Advances in Environmental Biology AENSI Journals, 11(3)(March), 75-80. http://www.aensiweb.com/aeb.html

Cheba, B. A., Zaghloul, T. I., El-Mahdy, A. R., \& El-Massry, M. H. (2018). Effect of nitrogen sources and fermentation conditions on bacillus sp. R2 chitinase production. Procedia Manufacturing, 22, 280-287. https://doi.org/10.1016/j.promfg.2018.03.043

Deng, S., Lorito, M., Penttilä, M., \& Harman, G. E. (2007). Overexpression of an endochitinase gene (ThEn-42) in Trichoderma atroviride for increased production of antifungal enzymes and enhanced antagonist action against pathogenic fungi. Applied Biochemistry and Biotechnology, 142(1), 81-94. https://doi.org/10.1007/s12010-007-0012-9

Donderski, W., \& Trzebiatowska, M. (2000). Influence of Physical and Chemical Factors on the Activity of Chitinases Produced by Planktonic Bacteria Isolated from Jeziorak Lake. 9(2), 77-82. 
Doumbou, C. L., Hamby Salove, M. K., Crawford, D. L., \& Beaulieu, C. (2001). Actinomycetes, promising tools to control plant diseases and to promote plant growth. Phytoprotection, 82(3), 85-102.

Duncan, S. M., Farrell, R. L., Thwaites, J. M., Held, B. W., Arenz, B. E., Jurgens, J. A., \& Blanchette, R. A. (2006). Endoglucanase-producing fungi isolated from Cape Evans historic expedition hut on Ross Island, Antarctica. Environmental Microbiology, 8(7), 1212-1219. https://doi.org/10.1111/j.1462-2920.2006.01013.x

E. B. Shirling and D. Gottlieb. (n.d.). METHODS FOR CHARACTERIZATION OF STREPTOMYCES SPECIES. INTERNATIONAL JOURNAL OF SYSTEMATIC BACTERIOLOGY, 16(3), 313-340.

El-Tarabily, K. A., Soliman, M. H., Nassar, A. H., Al-Hassani, H. A., Sivasithamparam, K., McKenna, F., \& Hardy, G. E. S. J. (2000). Biological control of Sclerotinia minor using a chitinolytic bacterium and actinomycetes. Plant Pathology, 49(5), 573-583.

Gangwar, M., Singh, V., Pandey, A. K., Tripathi, C. K. M., \& Mishra, B. N. (2016). Purification and characterization of chitinase from Streptomyces violascens NRRL B2700. Indian Journal of Experimental Biology, 54(1), 64-71.

Golinska, P., Wypij, M., Agarkar, G., Rathod, D., Dahm, H., \& Rai, M. (2015). Endophytic actinobacteria of medicinal plants: diversity and bioactivity. Antonie Van Leeuwenhoek, 108(2), 267-289.

Gomes, R. C., Semedo, L., Soares, R. M. A., Linhares, L. F., Ulhoa, C. J., Alviano, C. S., \& Coelho, R. R. R. (2001). Purification of a thermostable endochitinase from Streptomyces RC1071 isolated from a cerrado soil and its antagonism against phytopathogenic fungi. Journal of Applied Microbiology, 90(4), 653-661.

Hsu, S. C., \& Lockwood, J. L. (1975). Powdered chitin agar as a selective medium for enumeration of actinomycetes in water and soil. Applied and Environmental Microbiologymicrobiology, 29(3), 422-426. https://doi.org/10.1007/s10126-0119388-1

Jacquiod, S., Franqueville, L., Cécillon, S., M. Vogel, T., \& Simonet, P. (2013). Soil Bacterial Community Shifts after Chitin Enrichment: An Integrative Metagenomic Approach. PLOS ONE, 8(11), 1-13. https://doi.org/10.1371/journal.pone.0079699

Jahangiri, R., Jamialahmadi, K., Najafi, M. F., \& Vaccine, R. (2019). Purification and partial characterization of chitinase from a novel strain Aeromonas sp . PTCC 1691. 10(August), 590-597. 
Karunya, S. K., Reetha, D., Saranraj, P., \& Milton, D. J. (2011). Optimization and purification of chitinase produced by Bacillus subtilis and its antifungal activity against plant pathogens. International Journal of Pharmaceutical and Biological Archives, 2(6), 1680-1685.

Kawato, M., \& Shinobu, R. (1959). On Streptomyces herbaricolor nov. sp. Supplement: A Simple Technique for the Microscopic Observation. Mem Osaka Univ Lib Arts Educ B, 8, 114-119.

Kelly, K. L., \& Judd, D. B. (1976). Color: universal language and dictionary of names (Vol. 440). Department of Commerce, National Bureau of Standards, Center for Building ....

Kim, K.-J., Yang, Y.-J., \& Kim, J.-G. (2003). Purification and characterization of chitinase from Streptomyces sp. M-20. Journal of Biochemistry and Molecular Biology. https://doi.org/10.5483/BMBRep.2003.36.2.185

Lacombe-Harvey, M. È., Brzezinski, R., \& Beaulieu, C. (2018). Chitinolytic functions in actinobacteria: ecology, enzymes, and evolution. In Applied Microbiology and Biotechnology (Vol. 102, Issue 17, pp. 7219-7230). Applied Microbiology and Biotechnology. https://doi.org/10.1007/s00253-018-9149-4

Lingappa, Y., \& Lockwood, J. L. (1961). A chitin medium for isolation, growth and maintenance of actinomycetes. Nature, 189(4759), 158-159.

Lowry, O. H., Rosebrough, N. J., Farr, A. L., \& Randall, R. J. (1951). Protein measurement with the Folin phenol reagent. Journal of Biological Chemistry, 193(1), 265-275.

Massol-Deya, A. A., Odelson, D. A., Hickey, R. F., \& Tiedje, J. M. (1995). Bacterial community fingerprinting of amplified $16 S$ and 16-23S ribosomal DNA gene sequences and restriction endonuclease analysis(ARDRA) BT - Molecular Microbial Ecology Manual (A. D. L. Akkermans, J. D. Van Elsas, \& F. J. De Bruijn (eds.); pp. 289-296). Springer Netherlands. https://doi.org/10.1007/978-94011-0351-0_20

Miranda-Chavez, A. H. (1978). Chitinase Production of Arthrobacter sp. BN2. Oregon State University.

Mukesh, S., Pinki, D., \& Meenakshi, C. (2014). Actinomycetes : Source , Identification , and Their Applications Actinomycetes. International Journal of Current Microbiology and Applied Sciences, 3(2), 801-832.

Mukhtar, S., Zaheer, A., Aiysha, D., Abdulla Malik, K., \& Mehnaz, S. (2017). 
Actinomycetes: A Source of Industrially Important Enzymes. Journal of Proteomics \& Bioinformatics, 10(12), 316-319. https://doi.org/10.4172/jpb.1000456

Murata, T., Amarume, S., Hattori, T., Tokuyama, S., Tokuyasu, K., Kawagishi, H., \& Usui, T. (2005). Purification and characterization of a chitinase from Amycolatopsis orientalis with $N$-acetyllactosamine-repeating unit releasing activity. 336, 514-520. https://doi.org/10.1016/j.bbrc.2005.08.123

Nanjo, F., Katsumi, R., \& Sakai, K. (1990). Purification and characterization of an Exo$\beta$-D-glucosaminidase, a novel type of enzyme, from nocardia orientalis. Journal of Biological Chemistry, 265(17), 10088-10094. https://doi.org/10.1016/s00219258(19)38783-6

Oskay, A. M., Üsame, T., \& Cem, A. (2004). Antibacterial activity of some actinomycetes isolated from farming soils of Turkey. African Journal of Biotechnology, 3(9), 441-446.

Pridham, T. G., \& Gottlieb, D. (1948). The utilization of carbon compounds by some Actinomycetales as an aid for species determination. Journal of Bacteriology, 56(1), 107.

Reissig, J. L., Strominger, J. L., \& Leloir, L. F. (1955). A modified colorimetric method for the estimation of $\mathrm{N}$-acetylamino sugars. Journal of Biological Chemistry, 217(2), 959-966.

Rey, T., \& Dumas, B. (2017). Plenty is no plague: Streptomyces symbiosis with crops. Trends in Plant Science, 22(1), 30-37.

Santi, C., Bogusz, D., \& Franche, C. (2013). Biological nitrogen fixation in non-legume plants. Annals of Botany, 111(5), 743-767.

Shalaby, H., Abo-Sdera, S., Easa, S., \& Ismail, A.-M. (2019). Biosynthesis of biologically active chitinase utilizing some Egyptian chitinaceous wastes and the properties of the synthesized enzyme. Egyptian Pharmaceutical Journal, 18(4), 320. https://doi.org/10.4103/epj.epj_23_19

Shanmugaiah, V., Mathivanan, N., Balasubramanian, N., \& Manoharan, P. T. (2008). Optimization of cultural conditions for production of chitinase by Bacillus laterosporous MML2270 isolated from rice rhizosphere soil. African Journal of Biotechnology, 7(15), 2562-2568. https://doi.org/10.5897/AJB07.346

Shinobu, R. (1958). Physiological and cultural study for the identification of soil actinomycetes species. Osaka University. 
Shirling, E. B., \& Gottlieb, D. (1966). Methods for characterization of Streptomyces species1. International Journal of Systematic and Evolutionary Microbiology, 16(3), 313-340. https://doi.org/https://doi.org/10.1099/00207713-16-3-313

Shivalee, A., Lingappa, K., \& Mahesh, D. (2018). Influence of bioprocess variables on the production of extracellular chitinase under submerged fermentation by Streptomyces pratensis strain KLSL55. Journal of Genetic Engineering and Biotechnology, 16(2), 421-426. https://doi.org/10.1016/j.jgeb.2017.12.006

Singh, P. P., Shin, Y. C., Park, C. S., \& Chung, Y. R. (1999). Biological control of Fusarium wilt of cucumber by chitinolytic bacteria. Phytopathology, 89(1), 92-99.

Subramaniam, S., Ravi, V., \& Narayanan, G. K. (2012). Studies on Production of Enzyme Chitinase from Streptomyces sp. and its anti-fungal activity. J Pharm Res, 5(3), 1409-1413.

Tresner, H. D., \& Danga, F. (1958). Hydrogen sulfide production by Streptomyces as a criterion for species differentiation. Journal of Bacteriology, 76(3), 239.

Tweddell, R. J., Jabaji-Hare, S. H., \& Charest, P. M. (1994). Production of chitinases and beta-1,3, glucanases by Stachybotrys elegans, a mycoparasite of R. solani. App Env Microbiol, 60(2), 489-495.

Ulrike, E., Rogall, T., Blocker, H., Emde, M. and Bottger, E. C. (1989). Isolation and direct complete nucleotide determination of entire genes. Characterization of a gene coding for 16S ribosomal RNA. Nucleic Acid Research, 17(21), 7843-7853.

Vyas, P., \& Deshpande, M. V. (1989). Chitinase production by myrothecium verrucaria and its significance for fungal mycelia degradation. The Journal of General and Applied Microbiology, 35(5), 343-350. https://doi.org/10.2323/jgam.35.343

Wéry, N. (2014). Bioaerosols from composting facilities--a review. Frontiers in Cellular and Infection Microbiology, 4, 42. https://doi.org/10.3389/fcimb.2014.00042

Williams, S. T. (1989). Bergey's manual of systematic bacteriology. Williams \& Wilkins.

Yamaguchi, T. (1965). Comparison of the cell-wall composition of morphologically distinct actinomycetes. Journal of Bacteriology, 89(2), 444-453.

Yassine, H. (2013). Effects of ten years treated wastewater drip irrigation on soil microbiological properties under Mediterranean conditions. African Journal of Biotechnology, 12(39)(September),

5761-5770. https://doi.org/10.5897/AJB2013.12412 
Yildirim-Aksoy, M., Beck, B. H., \& Zhang, D. (2019). Examining the interplay between Streptococcus agalactiae, the biopolymer chitin and its derivative. MicrobiologyOpen, 8(5), 1-11. https://doi.org/10.1002/mbo3.733

\section{خصائص وتعريف والظروف المثلى لإنتاج الكيتيناز لنوع من الأكتينوميسيتات النادرة

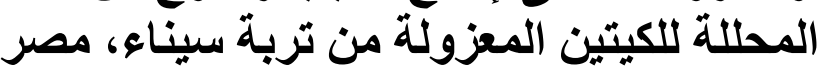

حمادة حسني البدوي'r,', عبد الناصر أحمد قبيصي'r, عزة عبد الخالق. عبدالخالق' , محمد أحمد البدري', *زينب خالد عبدالعزيز

'قسم النبات و الميكروبيولوجي- كلية العلوم(بنين)- جامعة الأزهر - القاهرة- مصر

'قشم وقاية النباتـ المركز القومي لبحوث الصحر اءـ القاهرة- مصر

"َقسم النبات و الميكروبيولوجيـ كلية العلوم(بنات)- جامعة الأزهر ـ القاهرة- مصر

zeinabsaleh.el20@azhar.edu.eg: البريد الاليكتروني للباحث الرئيسي

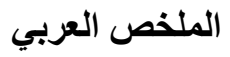

تهدف هذه الدراسة إلى عزل بعض الاكتينوميستات النادرة والمحللة للكيتين من عينات تربة من البيئة الصحراوية وخاصة سيناء مصر.

وخلال الدر اسة الحالية تم عزل الح عزلة أكتينوميسيته من عينات التربة وأظهرت النتائج أن 1 عزلات الكات فقط لها القدرة

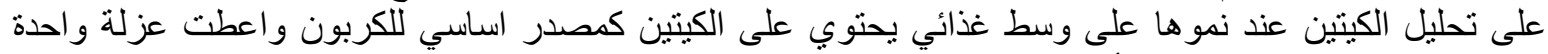

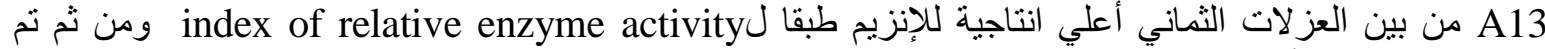

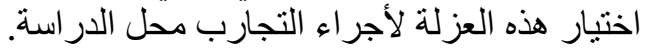

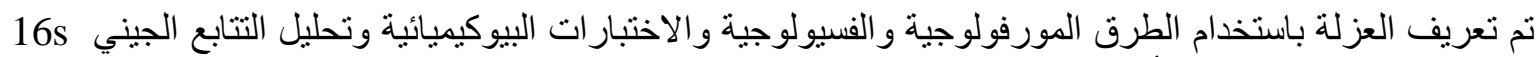

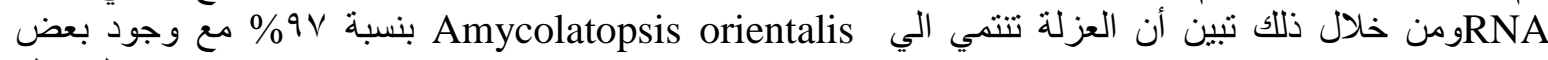

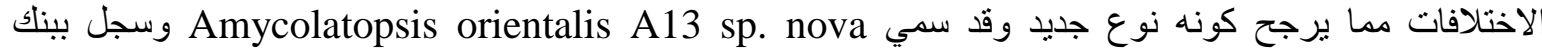

وبدر اسة الظروف المنلي لإتتاج إنزيم الكيتيناز المحلل للكيتين بو اسطة تلك العزلة تبين ما يلي:

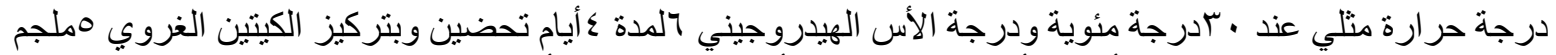

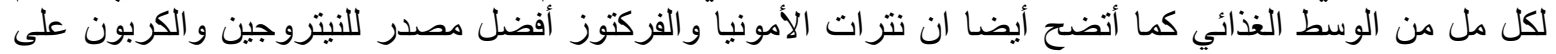
التوالي. الكلمات المفتاحية : الاكتينو ميستات , نادرة الوجود , تحلل للكيتين , تربة سيناء , انزيم الكيتيناز , الظروف المتلي 